\title{
Keys to Successful Innovation Strategy of Implementing Online Appraisal Performance
}

\author{
Dr. Kismartini, M.Si; Galih Wibowo; Edoardus E. Maturbong; Yearzy Ferdian; Karel Betaubun \\ Public Administration Doctoral Program, Faculty of Social and Political Sciences \\ Diponegoro University \\ Semarang City, Indonesia \\ (Prodi_dap@gmail.com/galih.akademik@gmail.com)
}

\begin{abstract}
E-government is one of innovation phenomenon that is done by its country bureaucracy system. Innovations are applied to support organization performance. But they aren't enough to reach the goal. The environmental strategic factors become innovation strategy that done to improve performance. While they can't be applied without nothing keys successful. Implementing this analysis into both of union management is done to find keys successful innovations strategy implementing.
\end{abstract}

Keywords-Appraisal; Environmental Strategic; Innovation; Keys Successful Strategy

\section{INTRODUCTION}

The important steps of public administration evolution are policy innovation appearing, that contain new policy direction and initiatives (LAN; 2014). At its country concept, innovation also occur when Governments use information technologies (ITs) to organize, communicate, and deliver services (McNutt; 2012) known as e-government. From time to time, innovation isn't always getting success (Franklin; 2003 and Christensen; 2003). In the other hand, it become a dilemma, for continuance organization activity in a long time that need commitment in always doing transformation through disruptive growth, but the fact shows there is only little company who get success in this case (Denning; 2005). This research is about modern management also find that information technology investment and production can't improve productivity without completing other development (Topkins; 1995). At the management strategy, environment is one of important contextual factor that impact into company performance (Hammel; 1999), so that inovative organization have to has commitment to control environment (Light, 1998). While innovation can be continue and support company performance that is need for innovation strategy (Light, 1998). It has to able mixing innovation effort and environmental organization for company performance. This is importance ways to looking for the keys successful implementation strategy in question.

Ministry of Industrialization Indonesian Republic is one of successful organization in environment control and innovation applying. It is developed innovation application named egovernment contains working appraising through online system. It is aimed to increased organization appraising through working hours effectiveness and budget utilizing efficiency. Working hour apparatus effectiveness has succeeded to be increased based on table 1 and 2 . The use of budget can be saved of 3.14 billion rupiah, by negating the need for the procurement server for 50 units amounted to 2.5 billion dollars, 500 million rupiah consultant fees, the stationery purchase and a facsimile of 80 million dollars, as well as the Elimination of shipping documents 60 million rupiah. The cost savings also implicates against the paperless concept, the human resources effectiveness, and encourage the human resources empowerment internal capacity because it negates external consultant.

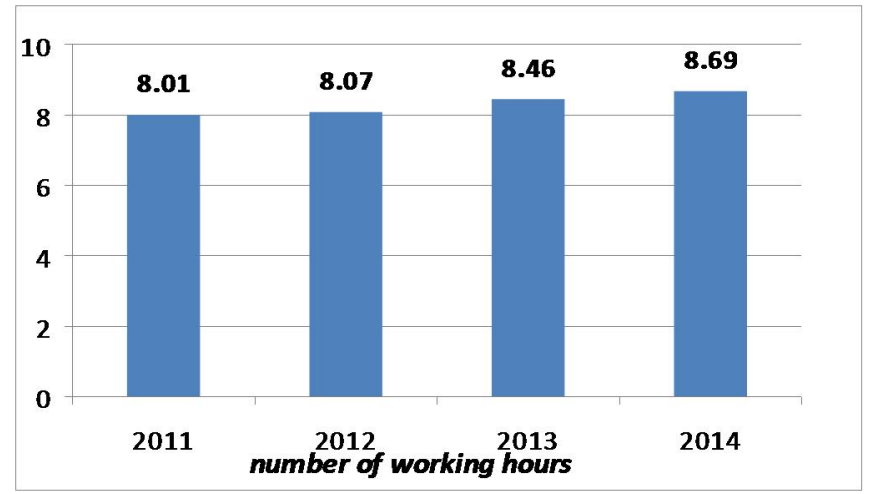

Fig. 1. Average Working Hour Increasing for Employee Taking 8 Hours Normative

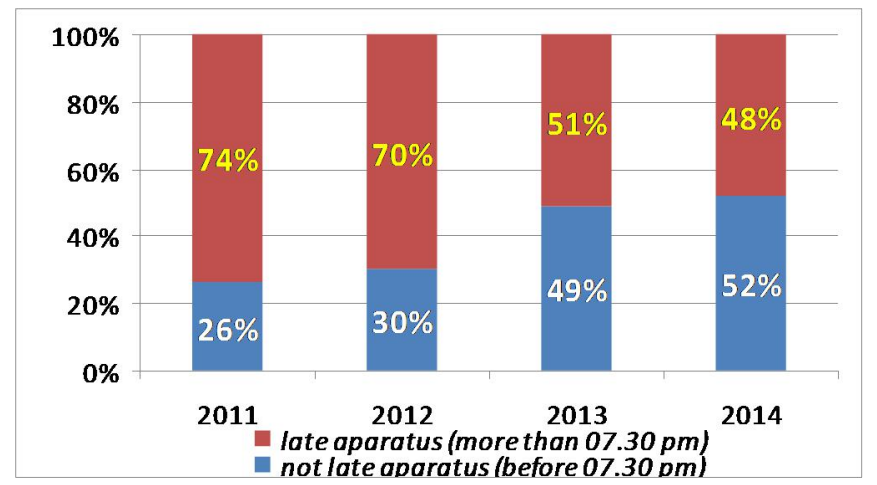

Fig. 2. Employee Percentage Who Come on time and Late (more than 7.30 am) 
Bases on the innovation success, the Ministry of industry is successfully awarded Bkn Award in the category Best no 1 in 2015 of implementation performance appraisal ministries/government agencies Non-Ministerial Department. The success of these triggers breakfast buffet to find out the key success of an innovation strategy.

\section{TheOretical Framework AND Method}

In the evolution era of Administration, the public organization analogous to the company, so as to move forward in innovation should have ability to generate competitiveness (Han; 2001), for business successful in the millennium century defined by innovation (Hammel; 1999). Innovation in the organization consists of various things, one of which factor technology (Abend; 2005) (Khalil; 2000). In addition to improving organizational performance needed intellectual investment (Edvinsson \& Malone; 1997) or innovation by leveraging the skills and resources (Jones; 2004). From the assumptions it can be said that innovation is comprised of technology, skills or intellectual abilities and resource management could be the drivers of organizational performance. This is in line with the opinion of the Organization illustrates that Barney is the merging of resources and ability to provide competitive advantage (Barney; 2002).

However, the resources and intellectual ability isn't enough to encourage performance (Youndt et al; 2004). On the other hand, knowledge and information alone also doesn't ensure the occurrence of innovation. (Jones; 2004), in a perspective of strategic management, the environment is an important contextual factor that impact on the company performance. Environmental factors include policy leadership/Government and law, technology, resources, and users taste (Hammel; 1994). So that innovation can be sustained and supported the company performance is required, innovation strategies that can be applied is radically, incremental or integrated (Terziovski, 2002). While the innovative terms organization is the need to have a commitment to control environment (Light, 1998). From the broad range of opinions, it can be mean that organizational performance successful is determined by the innovation strategy that combines innovation factors and environmental factors. A good innovation strategy is combining technology and intellectual resources, as well as the organization environmental factors that is the leadership policy, and the users attitude. Qualitative descriptive method with a round table discussion and observation is conducted to examine the legal and policy variables, technology, managing resources and user competence, so the keys success are found a strategy for innovation. Research conducted by 2015 at the Ministry of Industry of the Republic of Indonesia, in Jakarta.

\section{RESUlt AND Discussion}

E-government innovation policy at the Ministry of industry of Republic Indonesia has started since 2009. The year 2010 issues Ministerial Regulation to set up performance management. In 2012 the measurement mechanism of attendance system is replaced electronically connected with the intranet portal, and then serve as the basis for Performancebased Payments System attendance and employees performance. Innovation continues to be developed, up to 2014 has made Achievements Assessment system integrated, online work between attendance, the performance calculation and other system benefits. The scoring work system achievement integrates online employee such as these don't yet exist and used by other institutions. In addition, this system integrates advantages increase the effectiveness and efficiency, so as to spur the attitude of the leadership decide this innovative policy continued. Although Ministers changed, yet innovative policy such as this goes on. Even July 2015, the existing system is updated and enhanced with a variety programs, such as the ease of application of flexi-time for the apparatus are in the working area of Jakarta as a response to the obstacles severe traffic congestion often occurs. Flexi- time is the tolerance working hours by 15-minute delays for employees who must be replaced with the suspending return. Policy change leadership in providing tolerance associated with the application flexibility of goal setting for each work unit leader with the area character. The entire policy leadership is set out in a regulation of the Minister so it has strong levels legality to be implemented.

Technical efforts are undertaken in technology range -based measures. To support the smooth running of traffic data, Internet channels built with bandwidth of $2 \times 100 \mathrm{Mbps}$ for the data center. Both could mutually backing up, so if one dies or is in maintenance process, then the other will be backup, thereby servicing and performance will not be disturbed. The application system is also integrated with various other conveniences, such as staffing information system, e-budgeting, monitoring, e-file library or database activity, Intra fax to be used for distributing messages and commands or e-disposition alert system and equipped reminder gate away. Innovations online performance assessment is performed by human resources internal. The development needing system will be more easily implemented by the human resources at Ministry of industry compared to party consultants who need time for technology transfer and a huge budget allocation. In addition, internal party thus better understand technical connection requirements, and other factors related to innovation needing. Internal human resource involved in the creation applicationbased performance appraisal online is an impressive array Information technology experts and the Ministry of industry. During this time, they have produced various e-government products are also patentable, such as online licensing services, monitoring online and so on. In this case, can be said to be competence and experience managing human resources is already adequate.

Employee Performance attendance online system tested for first time in 2010 that are applied employee voluntary, without any reward - punishment. Since 2012, the system is treated in full with the reward punishment concept. Although it's been a long time applies, but socialization continues. Socializing done in interpersonal and utilize online means that exist in the application. Employees can download the rules and material dissemination or online tutorials, doing the questioning through Forum Discussion Online, or helpdesk contact to consult, and also provide mechanism complain. Container proposal facilitates complaints, criticism and suggestions. This aspiration is usually delivered the users when the system can't work a maximum or crash, and if found cheating or counting 
errors. Transparency in the appraising system noteworthy online performance, these parties could mutually supervise via the social control. Thus the clerk which one can correct an employee's performance is nothing more, so if it doesn't fit may report it as a complaint. Mechanisms to complain and transparency is becoming feedback for improvements system in the future.

\section{CONCLUSION}

Generally the innovations implemented by Ministry of industry of Indonesia applying performance system appraisal incremental innovation is Online, which earlier and far well prepared, even supported with technical and socialization efforts ranging from 2010 to 2015 still continues. From the description and variable analysis policy and law, technology, managing resources and users, the keys success is obtained which supports the implementation innovation strategy runs optimally are:

1) An attitude of tolerance, associated with the gradual implementation of the action, start 2010 in voluntary, the year 2012 is applied in full. Tolerance is a form of leadership wisdom, especially in changing work procedures and goal setting bases on the area condition, such as the existence of flexi time

2) Intensive Socialization, through many media, such as interactive communication, online tutorials, online discussion and helpdesk can help (problem solving) employees in using the application

3) The transparency process, supported the existence mechanism to accommodate criticism, suggestion and complaint users against cheating, thereby encouraging the presence of social supervision entire application user against another user.

\section{ACKNOWLEDGMENT}

This work as an application form of the science at Diponegoro University, along with expectations for presented and can be used broadly for development innovation bureaucracy.

\section{REFERENCES}

[1] Abend, C.J. (2005). In Search of Innovation Synthesis, Ideas for a Unified Innovation Theory, Technology Transfer Society.

[2] Barney, J.B. (2002). Gaining and Sustaining Competitive Advantage 2nd Edition, Pearson International Edition.

[3] Christensen, C.M., Raynor, M.E. (2003). The Innovator's Solution, Creating and Sustaining Successful Growth, Harvard Business School Publishing Corporation

[4] Edvinson, L. and Malone, M. (1997). Intellectual Capital: realizing Your Company's True Value by Finding Its Hidden Brainpower, HarperCollins Publisher, New York

[5] Franklin, C. (2003). Why Innovation Fails, Spiro Press

[6] Hammel, G. (1999). Leading the Revolution, Boston, MA, HBS Press

[7] Han, X. (2001). Intellectual capital and organization performance: interplay of knowledge management and human resources, Research Project Report Conference of National Science Council, I-Shou University, Kaosiung, 203-23

[8] Jones, G.R. (2004). Organizational Theory, Design, and Change, Prentice-Hall

[9] Khalil, T. (2000). Management of Technology, The Key to Competitiveness and Wealth Creation, McGraw Hill.

[10] Light, P. (1998). Sustaining Innovation: Creating Nonprofit and Government Organizations That Innovate Naturally, Jossey-Bass Publishers.

[11] McNutt, Kathleen. (2012). From the Outside In: The External Face of eGovernment. Journal of Information Technology \& Politics, 9:319-337. Copyright (C) Taylor \& Francis Group, LLC ISSN: 1933-1681 print/1933-169X online DOI: 10.1080/19331681.2012.727726

[12] Pusat Inovasi Tata Pemerintahan, Tim. (2014). Handbook Inovasi Administrasi Negara. Pusat Inovasi Tata Pemerintahan - Deputi Inovasi Administrasi Negara Lembaga Administrasi Negara. Jakarta

[13] Denning, Stephen , (2005). Transformational innovation: A journey by narrative, Strategy \& Leadership, Vol. 33 Iss: 3, pp.11 - 16

[14] Terziovski, M. (2002). Achieveing Performance Excellence Through an Integrated Strategy of Radical Innovation and Continuous Improvement, Measuring Business Excellence, (6), 2.

[15] Topkins, M, (1995). The economics of modern manufacturing, American Economic Review, (85),4, 991-5

[16] Youndt M., Subramaniam, M., Snell, S. (2004). Intellectual capital profiles: an examination of investment and return, Journal of Management Studies, (41), 2, 335-61

[17] http://www.kemenperin.go.id/artikel/12305/Kemenperin-Raih-BKNAwards-2015--Kategori-Implementasi-Penilaian-Kinerja-Terbaik 